\title{
Speciation of Heavy Metals in Sediment of Agbabu Bitumen deposit area, Nigeria
}

\author{
1*FAGBOTE, E O; ${ }^{2}$ OLANIPEKUN, E O \\ Department of Chemistry, The University of Ado-Ekiti, Nigeria. Ado-Ekiti, Nigeria. \\ Email:bunmifag@yahoo.com,eddylapek@yahoo.com \\ Tel: $+2347035483300 ;+2348033907371$
}

\begin{abstract}
Speciation of heavy metals $\mathrm{Cu}, \mathrm{Cd}, \mathrm{Pb}, \mathrm{Ni}, \mathrm{Zn}, \mathrm{Mn}, \mathrm{Fe}, \mathrm{Cr}$ and $\mathrm{Hg}$ was carried out on sediment of Agbabu with a sequential extraction procedure in the dry and rainy seasons of year 2008 . $\mathrm{Hg}$ was not detected in all the fractions in the two seasons. In the dry season, all the metals were mostly abundant in Fraction-5, however, Cr $(30 \%)$ and $\mathrm{Mn}(23.73 \%)$ had high abundance in Fraction-1, Zn $(30.97 \%)$ was high in Fraction-III, Cu (45.14\%) and $\mathrm{Fe}(31.67 \%)$ were also high in Fraction-4. In the rainy season, $\mathrm{Cr}(35.82 \%)$ was mostly abundant in Fraction- $1, \mathrm{Zn}$ $(36.71 \%)$ was high in Fraction-3, Cu (29.28\%) was high in Fraction-4 and the remaining metals were mostly abundant in Fraction-V. From the results of the two seasons, the metals had high abundance in Fraction-5 indicating firstly, low mobility and bioavailability, secondly, low degree of pollution by the metals considered and thirdly, the origin of the metals in the environment was likely to be lithogenic. The average potential mobility was calculated for the metals in the two seasons and the following decreasing order was obtained: $\mathrm{Cr}>\mathrm{Zn}>\mathrm{Cu}>\mathrm{Mn}>\mathrm{Fe}>\mathrm{Cd}>\mathrm{Ni}>\mathrm{Pb}>\mathrm{Hg}$. @ JASEM
\end{abstract}

Bitumen was first discovered in Nigeria in 1910. The first bitumen well NBC-7 was drilled at Agbabu in Ondo State in the South Western part of Nigeria. Heavy metals are present everywhere in the environment (Adekola, 2002). Today it is generally recognized that the particular behavior of trace metals in the environment is determined by their specific physicochemical forms rather than by their total concentration. Speciation of metals largely determines their bioavailability and toxicity (Tack and Verloo, 1995). Speciation can be defined as identification and quantification of the different species or forms of phases in which elements occur. It is generally recognized that information about the physicochemical forms of the elements is required for understanding their mobility, pathways and bioavailability. Studies on the distribution and speciation of heavy metals in sediments can provide not only information on the degree of pollution, but specially the actual environmental impact, metal bioavailability as well as their origin (Ramirez, 2005).

Heavy metal speciation in sediment impacted with crude oil in the Niger-Delta region of Nigeria has been reported (Iwegbue et al., 2006). It was found that $\mathrm{Cd}, \mathrm{Pb}, \mathrm{Zn}$, and $\mathrm{Ni}$ have high mobility indices. $\mathrm{Cd}$ was associated with easily Exchangeable/Adsorbed and Carbonate fractions, $\mathrm{Cu}$ and $\mathrm{Cr}$ predominantly occur in Organic and Residual fractions. Zn was associated with Carbonate and $\mathrm{Fe}$ Mn oxide fractions (Iwegbue et al., 2006). Olajire et al. (2003) studied the levels and speciation of five heavy metals in soils of industrial Southern Nigeria and found that the highest amount of $\mathrm{Cd}$ was found in the Exchangeable fraction and $\mathrm{Cu}$ and $\mathrm{Zn}$ were significantly associated with the Organic fraction. Some studies have been carried out on the Nigerian bitumen and Agbabu Bitumen deposit such as multielemental analysis (Adebiyi et al, 2006), environmental impact assessment of bitumen exploitation on animal resources of Ode - Irele (Lameed and Ogunsusi, 2002), compositional analysis of the oil component of the Nigerian bitumen (Oderinde and Olanipekun, 1991), Distribution of Polycyclic Aromatic hydrocarbons in soils and water from the vicinity of Agbabu bitumen field (Olajire et al., 2007), and solvent extraction of vanadium from Nigerian bitumen (Oguntimehin and Ipinmoroti, 2007). The need for this research arose because no study has been reported on the speciation of metals in sediment of Agbabu bitumen deposit environment.

\section{MATERIALS \& METHODS}

Samples were collected from four sediment locations in the dry season and two sediment locations in the rainy season. Sampling points were geo-located with Geographical Position System (GPS) to ensure consistency. Samples were collected in polythene bags. Dirt and other unwanted substances were removed from the samples and oven dried at $105^{\circ} \mathrm{C}$ before sieving. All reagents used were of analytical grade. The sequential extraction scheme was followed (Tessier et al, 1979; Abu-Kukati, 2001). Five fractions of the sample solutions were prepared in assessing the effect of changing environment conditions.

Fraction I - Exchangeable fraction: Samples (1g) of sediment were extracted at room temperature for 1hour with $16 \mathrm{ml}$ of $\mathrm{MgCl}_{2}$ solution $(1 \mathrm{M} \mathrm{MgCl} 2)$ at $\mathrm{pH}$ 7. Sediment and extraction solution were thoroughly agitated throughout the extraction. This is mainly an adsorption - desorption process. Metals extracted in the exchangeable fraction include weakly 
adsorbed metals and can be released by ion-exchange process. Changes in the ionic composition of the water would strongly influence the ionic exchange process of metal ions with the major constituents of the samples like clays, hydrated oxides of iron and manganese (Abu-Kukati, 2001). The extracted metals were then decanted from the residual sediment.

Fraction II - Bound to carbonates: The metals bound to carbonate phase are affected by ion exchange and changes of $\mathrm{pH}$. The residue of Fraction 1 was extracted with $16 \mathrm{ml}$ of $1 \mathrm{M}$ sodium acetate/acetic acid buffer at $\mathrm{pH} 5$ for 5 hours at room temperature. Significant amount of trace metals can be coprecipitated with carbonates at the appropriate $\mathrm{pH}$. The extracted metal solution was decanted from the residual sediment. The residual sediment was used for the next extraction.

Fraction III - Bound to iron and manganese oxides:The residue from fraction 2 was extracted under mild reducing conditions. $13.9 \mathrm{~g}$ of hydroxyl amine hydrochloride $\left(\mathrm{NH}_{2} \mathrm{OH} . \mathrm{HCl}\right)$ was dissolved in $500 \mathrm{ml}$ of distilled water to prepare $0.4 \mathrm{M}$ $\mathrm{NH}_{2} \mathrm{OH} . \mathrm{HCl}$. The residue was extracted with $20 \mathrm{ml}$ of $0.4 \mathrm{M} \mathrm{NH} \mathrm{N}_{2} \mathrm{OH} . \mathrm{HCl}$ in $25 \%(\mathrm{v} / \mathrm{v})$ acetic acid with agitation at $96^{\circ} \mathrm{C}$ in a water bath for 6hours. Iron and manganese oxides which can be present between particles or coatings on particles are excellent substrates with large surface areas for absorbing trace metals. Under reducing conditions, Fe (III) and $\mathrm{Mn}$ (IV) could release adsorbed trace metals. The extracted metal solution was decanted from the residual sediment which was used for the next extraction.

Fraction IV - Bound to organic matter and sulphide: The residue from fraction 3 was oxidized as follows: $3 \mathrm{ml}$ of $0.02 \mathrm{M} \mathrm{HNO}_{3}$ and $5 \mathrm{ml}$ of $30 \%(\mathrm{v} / \mathrm{v})$ hydrogen peroxide, which has been adjusted to $\mathrm{pH} 2$, were added to the residue from fraction 3. The mixture was heated to $85^{\circ} \mathrm{C}$ in a water bath for 2 hours with occasional agitation and allowed to cool down. Another $3 \mathrm{ml}$ of $30 \%$ hydrogen peroxide, adjusted to
$\mathrm{pH} 2$ with $\mathrm{HNO}_{3}$, was then added. The mixture was heated again at $85^{\circ} \mathrm{C}$ for $3 \mathrm{hrs}$ with occasional agitation and allowed to cool down. Then $5 \mathrm{ml}$ of $3.2 \mathrm{M}$ ammonium acetate in $20 \%$ (v/v) $\mathrm{HNO}_{3}$ was added, followed by dilution to a final volume of $20 \mathrm{ml}$ with de-ionized water. Trace metals may be bound by various forms of organic matter, living organisms and coating on mineral particles through complexation or bioaccumulation. These substances may be degraded by oxidation leading to a release of soluble metals. The extracted metal solution was decanted from the residual sediment which was used for the next extraction.

Fraction $V$-Residual or inert fraction: Residue from fraction 4 was oven dried at $105^{\circ} \mathrm{C}$. Digestion was carried out with a mixture of $5 \mathrm{ml}$ conc. $\mathrm{HNO}_{3}$ $\left(\mathrm{HNO}_{3}, 70 \% \mathrm{w} / \mathrm{w}\right), 10 \mathrm{ml}$ of hydrofluoric acid (HF, $40 \% \mathrm{w} / \mathrm{w})$ and $10 \mathrm{ml}$ of perchloric acid $\left(\mathrm{HClO}_{4}\right.$, $60 \% \mathrm{w} / \mathrm{w})$ in Teflon beakers. Fraction 5 largely consists of mineral compounds where metals are firmly bonded within crystal structure of the minerals comprising the sediment.

Analysis was carried out with AAS using GBC Avanta PM. Ver 2.02. To validate the procedure, the instrument was programmed and it carried out metal detection by displaying three absorbance readings and what was reported was the average. Blanks were also used for correction of background and other sources of error. Apart from calibration before use, quality checks were also performed on the instrument by checking the absorbance after every ten sample runs.

\section{RESULTS AND DISCUSSION}

The results of the sequential extraction of the sediment samples in the dry season (March 2008) rainy season (August 2008) are summarized in Table 1. The percentages of metals in the fractions are represented graphically in Figure 1 for dry and rainy seasons.

Table 1: Seasonal variation of heavy metal fractions in the study area. ( $F=$ FRACTION; $D=$ dry season; $\mathrm{R}=$ rainy season)

\begin{tabular}{|c|c|c|c|c|c|c|c|c|c|c|c|c|c|c|c|c|c|c|}
\hline $\mathrm{F}$ & \multicolumn{2}{|c|}{$\mathrm{Cu}(\%)$} & \multicolumn{2}{|c|}{$\mathrm{Cd}(\%)$} & \multicolumn{2}{|c|}{$\mathrm{Pb}(\%)$} & \multicolumn{2}{|c|}{$\mathrm{Ni}(\%)$} & \multicolumn{2}{|c|}{$\mathrm{Zn}(\%)$} & \multicolumn{2}{|c|}{$\operatorname{Mn}(\%)$} & \multicolumn{2}{|c|}{$\mathrm{Fe}(\%)$} & \multicolumn{2}{|c|}{$\operatorname{Cr}(\%)$} & \multicolumn{2}{|c|}{$\mathrm{Hg}(\%)$} \\
\hline & $\mathrm{D}$ & $\mathrm{R}$ & D & $\mathrm{R}$ & $\mathrm{D}$ & $\mathrm{R}$ & $\mathrm{D}$ & $\mathrm{R}$ & D & $\mathrm{R}$ & $\mathrm{D}$ & $\mathrm{R}$ & D & $\mathrm{R}$ & D & $\mathrm{R}$ & $\mathrm{D}$ & $\mathrm{R}$ \\
\hline $\mathrm{F} 1$ & 0.6 & 0.0 & 7.2 & 2.8 & 0.3 & 0.0 & 2.0 & 2.6 & 4.6 & 0.5 & 20.7 & 5.3 & 0.7 & 0.0 & 31.0 & 35.8 & 0.0 & 0.0 \\
\hline $\mathrm{F} 2$ & 0.0 & 0.0 & 11.5 & 13.4 & 0.0 & 0.0 & 2.4 & 3.4 & 9.5 & 12.5 & 10.0 & 4.5 & 0.1 & 0.1 & 11.4 & 19.4 & 0.0 & 0.0 \\
\hline F3 & 8.9 & 5.2 & 12.6 & 17.9 & 3.5 & 1.5 & 8.6 & 9.6 & 31.0 & 36.7 & 17.1 & 12.4 & 19.3 & 15.3 & 14.1 & 13.2 & 0.0 & 0.0 \\
\hline F4 & 45.1 & 29.3 & 4.0 & 4.0 & 2.9 & 2.6 & 5.6 & 3.5 & 10.5 & 9.0 & 9.5 & 8.7 & 31.7 & 17.0 & 5.7 & 0.0 & 0.0 & 0.0 \\
\hline F5 & 45.4 & 65.6 & 64.7 & 61.9 & 93.3 & 95.9 & 81.3 & 81.0 & 44.5 & 41.2 & 42.6 & 69.1 & 48.3 & 67.5 & 37.6 & 31.5 & 0.0 & 0.0 \\
\hline
\end{tabular}


In the dry season, all the heavy metals were mostly abundant in the Residual or Inert fraction as follows: $\mathrm{Cu}$ (45.14\%), $\mathrm{Cd}$ (64.66\%), $\mathrm{Pb}$ (93.26\%), $\mathrm{Ni}$ (81.28\%), Zn (44.46\%), Mn (42.55\%), Fe (48.25\%) and $\mathrm{Cr}(37.85 \%)$. However, $\mathrm{Cr}(30.97 \%)$ and $\mathrm{Mn}$ $(23.73 \%)$ were also very abundant in the Exchangeable fraction. Zn (30.97\%) was also high in the fraction Bound to Iron and Manganese; $\mathrm{Cu}$ $(45.14 \%)$ and $\mathrm{Fe}(31.67 \%)$ were high in the fraction Bound to Organic matter and sulphides. These indicate that $\mathrm{Mn}, \mathrm{Cr}, \mathrm{Zn}, \mathrm{Cu}$ and $\mathrm{Fe}$ had higher bioavailability in sediment than other metals such as $\mathrm{Cd}, \mathrm{Pb}, \mathrm{Ni}$ which were mainly available in the Residual or Inert fraction in the dry season. In the rainy season, $\mathrm{Cr}$ was mostly abundant in the
Exchangeable fraction (35.82\%) while the remaining metals were mostly abundant in the Residual or Inert fraction as follows: $\mathrm{Cu}(65.57 \%), \mathrm{Cd}(61.86 \%), \mathrm{Pb}$ (95.89\%), Ni (80.96\%), Zn (41.21\%), Mn (69.11\%) and $\mathrm{Fe}(67.53 \%)$. $\mathrm{Zn}(36.71 \%)$ was also found to have high abundance in the fraction Bound to Iron and Manganese oxides and $\mathrm{Cu}(29.28 \%)$ in the fraction Bound to organic matter and sulphides in the rainy season. This shows that $\mathrm{Cr}$ was more available and mobile, followed by $\mathrm{Zn}$ and $\mathrm{Cu}$ in the rainy season. Generally, from the results of the two seasons, the metals were mostly abundant in the Residual or Inert fraction implying low mobility and bioavailability. It also indicates probably a low degree of pollution by the metals considered.

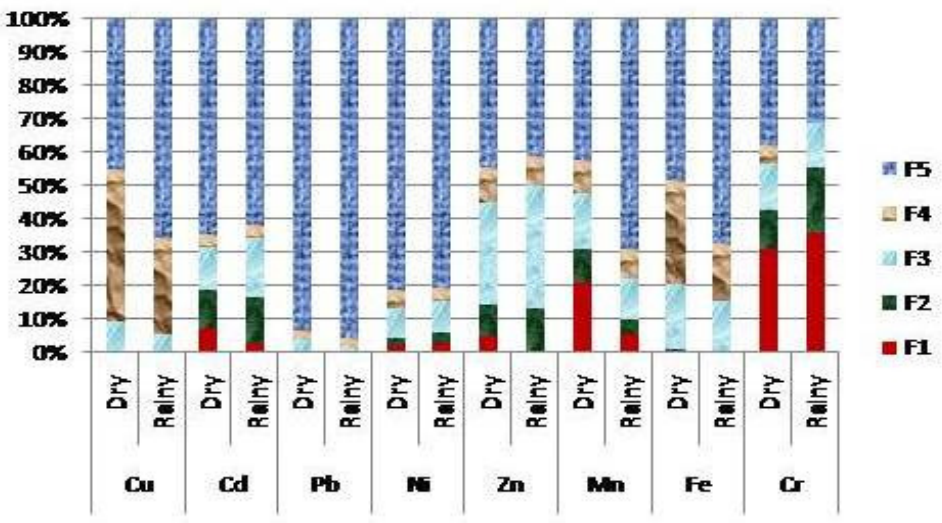

Fig 1: Seasonal variation of heavy metal fractions in the study area

The sum of different phases of metals can be used to express the potential mobility of metals. The potential mobility of a metal can be assessed by adding up the results of the Exchangeable phase, Carbonate phase, Fe-Mn oxide phase and organic phase of that metal (Haung et al 2007). The potential mobility of $\mathrm{Cr}$ in sediment in the dry season was $62.15 \%$ while it increased to $68.48 \%$ in the rainy season. The percentage reduction in concentration from March to August in sediment was $14.28 \%$. The high potential mobility of $\mathrm{Cr}$ in the environment was confirmed with the percentage reduction in concentration of $\mathrm{Cr}$ between March and August. In sediment samples, $\mathrm{Zn}$ had very high abundance in the fraction Bound to Iron and Manganese oxides. The abundance was $30.97 \%$ in the dry season and $36.71 \%$ in the rainy season. This is in agreement with Zerbe et al, 1999. This accounts for high percentage potential mobility of $\mathrm{Zn}$ in the dry season $(55.54 \%)$ and rainy season $(58.79 \%)$. The percentage reduction in concentration between March and August was $14.26 \%$

Copper can easily complex with organic matters because of the high formation of organic- $\mathrm{Cu}$ compounds (Haung et al 2007). The result of sequential extraction shows that in the sediment samples, $\mathrm{Cu}$ in the fraction Bound to Organic matter and Sulphides was very high in the dry season $(45.14 \%)$ and rainy season $(29.28 \%)$. Heavy metals Bound to Organic matter and Sulphides are more available than the heavy metals in the residue fraction. Therefore, the potential mobility of $\mathrm{Cu}$ in sediment in the dry season was $54.64 \%$ and $34.43 \%$ in the rainy season. The percentage reduction in concentration in sediment samples between March and August is $58.07 \%$ (Table 1). The remaining heavy metals studied in sediment samples $(\mathrm{Cd}, \mathrm{Pb}$, $\mathrm{Ni}, \mathrm{Mn}$, and $\mathrm{Fe}$ ) are mostly abundant in the Residual fraction. This agrees with Ramrez et al. (2005) who reported that $\mathrm{Cd}, \mathrm{Fe}, \mathrm{Mn}, \mathrm{Ni}$ and $\mathrm{Pb}$ were mostly associated with the residual phase. Metals present in the residual fraction are a measure of the degree of environmental pollution. The higher the metals present in this fraction, the lower the degree of pollution (Banat, 2001).

Metals with anthropogenic origin are mainly extracted in the first step of sequential extraction procedures while lithogenic metals are found in the 
last step of the process corresponding to the residual fraction (Ramirez, 2005). Metals at Agbabu bitumen deposit area, from the results of sequential extraction, were mostly lithogenic. In the sediment samples analyzed, apart from $\mathrm{Cr}, \mathrm{Zn}$ and $\mathrm{Cu}$, other metals such as $\mathrm{Cd}, \mathrm{Pb}, \mathrm{Ni}, \mathrm{Mn}$ and Fe were highly abundant in the residue, implying that they were not derived from anthropogenic sources. Adebiyi et al. (2006) carried out an elemental characterization of the Nigerian bitumen by total reflection X-ray fluorescence which showed $\mathrm{Fe}, \mathrm{Cr}$ and $\mathrm{Mn}$ to be part of its components. Trace elements such as transition metals get into bitumen in form of porphyrin complexes in its early stages of formation. The Nigerian bitumen components were also subjected to trace metal analysis and were found to contain high concentrations of $\mathrm{Zn}, \mathrm{Ni}, \mathrm{V}$ and $\mathrm{Fe}$. (Adebiyi and Omode, 2007). Therefore, the only likely lithogenic source of heavy metals at Agbabu environment is bitumen.

Metal chemical speciation carried out by sequential extraction of the metals is essential to the metal mobility (Tessier et al., 1979). The order of mobility of the metals considering their abundance in the fractions is: Exchangeable $>$ Bound to carbonate $>$ Bound to Iron and $\mathrm{Mn}$ oxides $>$ Bound to organic matter and sulphide $>$ Residual (Tesser et al. 1979). Iron and Manganese oxides exist as nodules and cement between particles. These oxides hold trace metals and can be mobilized under reducing and acidic conditions. The organic phase is relatively stable in nature but can be mobilized under strong oxidizing conditions due to degradation of organic matter (Tessier et al., 1979; Haung et al., 2007).

From the result of the sequential extraction in all the sediment samples studied, $\mathrm{Cr}$ was highly abundant in the samples fraction Exchangeable. The average potential mobility sediment for the two seasons was $65.31 \%$. This shows that $\mathrm{Cr}$ was highly mobile and available in the environment and highly toxic. $\mathrm{Zn}$ was highly abundant bound to $\mathrm{Fe}$ and Mn oxides and the average potential mobility of $\mathrm{Zn}$ in the two seasons was $57.16 \%$ in sediment. Under reducing and acidic conditions, $\mathrm{Zn}$ could easily be mobilized to the environment. Therefore compared with other metals that are mostly abundant in the residue fraction $\mathrm{Zn}$ was more available and toxic in the environment. The abundance of $\mathrm{Cu}$ in the fraction Bound to organic matter and sulphides in sediment in the dry season was $41.14 \%$ while it was $29.28 \%$ in the same fraction in the rainy season, thereby making it more mobile than the metals that were mostly abundant in the residual fraction. The average potential mobility of $\mathrm{Cu}$ was $44.54 \%$ in sediment. Under strong oxidizing conditions, due to degradation of organic matter, $\mathrm{Cu}$ becomes very available and toxic in the environment. The remaining metals $\mathrm{Cd}, \mathrm{Pb}, \mathrm{Ni}, \mathrm{Mn}$ and $\mathrm{Fe}$ were mostly abundant in the residual fraction which shows they were less available and immobile compared with other metals in the environment. More metals are present in this fraction than in the other fractions which showed that the degree of pollution in the environment was low.

Conclusion: $\mathrm{Hg}$ was not detected in all the samples tested. The order of average potential mobility sediment agrees with the percentage reduction in concentration. However value of the percentage reduction in concentration for $\mathrm{Ni}$ in sediment was negative. This shows that the actual behavior of $\mathrm{Ni}$ may be controlled not only by its speciation, changes in $\mathrm{pH}$ and salinity, but also by unknown factors (Haung et al., 2007). The speciation of heavy metals in Agbabu bitumen deposit area showed that most of the metals considered had the highest abundance in the residual fraction. This indicates that the metals were immobile. Nine metals were considered $\mathrm{Hg}$ was not detected at all in all the samples, $\mathrm{Cd}, \mathrm{Pb}, \mathrm{Ni}, \mathrm{Mn}$ and $\mathrm{Fe}$ were found mostly abundant in the residual fraction of the sequential extraction. This shows that the environment is not likely to be polluted by these metals. $\mathrm{Cr}$ was found to be highly abundant in the exchangeable fraction, indicating that it could be easily released to the environment and be of high toxicity in the environment. The average potential mobility of the metals can be arranged in decreasing order for sediment as follows: $\mathrm{Cr}>\mathrm{Zn}>\mathrm{Cu}>\mathrm{Mn}>\mathrm{Fe}>\mathrm{Cd}>\mathrm{Ni}>\mathrm{Pb}>\mathrm{Hg}$.The average potential mobility of $\mathrm{Zn}$ and $\mathrm{Cu}$ in sediment samples studied were quite high implying that under favourable conditions they can be released to pollute the environment. The results of the speciation have given the present status of metal pollution and the potential pollutants in Agbabu bitumen area. Research can be carried out further on the speciation of heavy metals in surface water and ground water in the vicinity.

\section{REFERENCES}

Abu-Kukati, Y (2001). Heavy metal distribution and speciation in sediments from Ziglab DamJordan. Geol

Engineering 25(1): 33-40

Adebiyi, F M; Asubiojo, OI; Ajayi, TR (2006). Multi-elemental analysis of Nigerian bitumen by TXRF spectrometryand the physical constants characterization of its hydrocarbon content. Fuel 85(3): $396-400$

Adebiyi, FM; Omode, AA (2007). Chemical and elemental characterization of components of 
Nigerian bitumen sands. Energy sources 29( 8): 669-676

Adekola, FA; Eletta, OA; Atanda, SA (2002). Determination of some heavy metals in Urban run-of sediments in Ilorin and Lagos, Nigeria. J Appl Sci Environ Manage 6 (2): 23-26

Banat, KM (2001). Assessment of Fe, Ni, Cd, Hg and $\mathrm{Pb}$ in the Jordan and Yarmonk River sediments in relation to their physicochemical properties and sequential extraction characterization. Water, Air, Soil Pollutant 132 (1-2): 43-59.

Haung, J; Haung, R; Jiao, JJ; Chen, K (2007). Speciation and mobility of heavy metals in mud, in coastal reclamation areas in Chenzhen, China. Environ Geol 53: 221-228

Iwegbue CMA; Armioro FO; Onyenibe, S (2006). Study of heavy metal speciation in sediments impacted, with crude oil in the Niger Delta, Nigeria. J of Societ Chimic Italia 97(11-12): $1143-1155$

Lameed, GA; Ogunsusi K (2002). Environmental impact assess of bitumen exploitation on animal resources of Ode -Irele Forest area. Afr $\mathrm{J}$ of Livestock Ext 1:15 - 21

Oderinde, RA; Olanipekun, EO (1991). Composition analysis of the oil component of the Nigerian bitumen. J Afr Earth Sci 12(3): 483 - 487
Oguntimehin, II; Ipinmoroti KO (2007). Solvent extraction of vanadium from Nigerian bitumen using Tri-

butylphosphate. J of Appl Sci 7(24): 4028-4031

Olajire, AA; Alade, OA; Adeniyi, AA; Olabemiwo, MO (2007). Distribution of Polycyclic Aromatic Hydrocarbons in surface soils and water from the vicinity of Agbabu bitumen field of Southwestern Nigeria. J of Environ Sci and Health, Part A 42(8): 1043 - 1049

Olajire, A.A., Ayodele, ET; Oyediran, GO; Oluyemi, EA (2003). Levels and Speciation of heavy metals in soils of Industrial Southern Nigeria, Environ Monit and Assessment, Springer Netherlands 85: 135-155.

Ramirez, M; Massolo, S; Fraiche R; Correa, JA (2005). Metal speciation and environmental impact on sandy beaches due to El Salvador Coppermine, Chile. Marine Pollution Bull 50:62-71

Tack, MF; Verloo, GM (1995). Chemical speciation and fractionation in soil and sediment heavy metal analysis-a review. Int $\mathbf{J}$ of Environ Anal Chem 59: 225-238

Tessier, A; Campbell, PGC; Bission, M (1979). Sequential extraction procedures for the speciation of trace metals. Anal Chem 51(7): 844-851

Zerbe, J; Sobezynski, T; Elabanowska, H; Siepak, J (1999). Sediments of Lakes, Speciation of Heavy metals in Bottom Sediment of Lakes. Pol J of Environ Studies 8(5): 331-339 